\title{
LITERATURE READ WRITE AND RELATED WITH THE DEVELOPMENT OF INDONESIAN TEACHING MATERIALS
}

\author{
Maharani Dwi Putri Asriati \\ Master's Program Faculty of Languages and Arts, Padang State University \\ maharanidwipuriasriati@gmail.com
}

\begin{abstract}
Literacy ability was originally defined as the ability to read and write, but now understanding has developed. In the field of study, literacy is an important ability that every student must have to master various subjects. In accordance with the explanation in the 2013 curriculum that language is the driver of knowledge, Indonesian is a means of delivering knowledge. Literacy is the basis in the formation of a multi-educated personality. The national curriculum places an important task for schools by predicting general educational goals and public requirements, to develop the literacy competencies of Tavdgiridze students (in Vivi, et al 2016). Everyone who has learned of course often reads, especially in knowing something in written form, reading activities are very necessary.
\end{abstract}

Children's language skills, especially reading and writing, which are obtained through Indonesian language lessons, will determine their success in mastering various other subjects. Especially for Indonesian subjects, the notion of literacy is focused on information skills. Information capability refers to several activities, namely gathering information, processing information, and communicating information. These three activities cannot be separated from reading and writing skills, which are carried out by teachers and students in the learning process in class. This kind of activity is in accordance with the demands of the learning process according to the 2013 Curriculum which is known as the scientific approach. In relation to the implementation of literacy learning, the teacher must pay attention to four aspects, namely learning resources, teaching materials, learning strategies, and assessments. According to Agustina (in Syahrul, et al 2017) Indonesian language learning at every level of education starting from elementary school to the next level is oriented towards improving students' Indonesian language skills. Mastery of language skills is still used as the main achievement in learning Indonesian.

Language has a central role in the intellectual, social, and emotional development of students. Language is to support success in learning. Language learning is expected to help students get to know themselves, their culture, and other people. In addition, language is used to express ideas and feelings, participate in society, discover and use their own analytical and imaginative abilities. 
(MoNE, 2007 in Novelti, et al). Children's language skills are obtained through learning Indonesian, especially reading and writing. Language plays an important role in human life. Language can develop Arief's intellectual, emotional, and spiritual intelligence (in Ramadhan, et al 2017). Especially for Indonesian subjects, the concept of literacy focuses on information skills. Information capability refers to various activities, namely gathering information, processing information, and exchanging information. These three activities are inseparable from the reading and writing skills carried out by teachers and students in the learning process in the classroom. This kind of activity meets the requirements of the 2013 course learning process and is called the scientific method. In the implementation of literacy learning,

Literacy is closely related to the development of teaching materials. If students can master the lesson then education will also run smoothly. Education as a benchmark for the progress of the nation requires comprehensive attention on how to develop technology-based education. Educational institutions must provide sufficient space for technological development, which is expected to help the learning process carried out in the classroom effectively (in Syarul R, et al 2019). 


\section{BIBLIOGRAPHY}

Gusnetti, M. Zaim, Syahrul R, and Agustina. 2019. The Effect of Sq3r Reading Techniques on Reading Comprehension of Fkip Students, Bung Hatta University, Padang. Ta'dib Journal. IAIN Stone Cage.

Mulyadi, Syahrul R, et al. 2019. The Development E-Modules Based on Adobe Flash For Indonesian on Course Indonesian. Atlantis Press.

Novelti, Syahrul, R., Ermanto, Agustina. 2018. Developing an Instructional Model Assisted Audio Visual Media. Atlantis Press.

Sucia, Syahrul R, et al. 2019. The Development Of Electronic Module Based On Discovery Learning In Writing Explanation Test. Atlantis Press.

Subandiyah, Heny. 2017. Literacy Learning in Indonesian Language Subjects. Paramasstra.

Syahrul Ramadhan, Yasnur Asri, Vivi Indriyani. 2018.Learning Module Design Writing Argumentative Text Based Problem-Based Learning. Atlantis Press.

Vivi Indriyani, M. Zaim, Atmazaki, Syahrul Ramadhan. 2019.Literacy, Reading and Innovation Language Curriculum. Kembara: Scientific Journal of Language, Literature, and Its Teaching. 